\title{
ACQUIRED HAEMOLYTIC ANAEMIA : SURVIVAL OF TRANSFUSED ERYTHROCYTES IN PATIENTS AND NORMAL RECIPIENTS
}

\author{
BY \\ J. G. SELWYN AND W. E. R. HACKETT \\ From the South-West Regional Blood Transfusion Centre, Bristol
}

(ReCEIVed for pUblication, 'AUgust 9, 1948)

Evidence of a difference in the mechanism of haemolysis between congenital and acquired haemolytic anaemia (acholuric jaundice) has been revealed by studies of the survival of transfused erythrocytes and by the direct Coombs test (Coombs and others, 1945a, b). Dacie and Mollison (1943) showed that normal erythrocytes transfused into cases of congenital haemolytic anaemia survived normally, but the erythrocytes from such cases when transfused into normal persons were rapidly eliminated. Moreover, these erythrocytes give a negative direct Coombs test (Boorman and others, 1946) and are referred to in this paper as "unsensitized." In contrast, erythrocytes from cases of acquired haemolytic anaemia give a positive direct Coombs test (Boorman and others, 1946) and may thus be referred to as " sensitized." Normal erythrocytes transfused to these patients are rapidly eliminated, but the patients' own erythrocytes survive normally when transfused into normal persons (Loutit and Mollison, 1946). This evidence, Loutit and Mollison suggested, indicates that the erythrocytes in acquired haemolytic anaemia are sensitized by an antibody or haemolysin; and their normal survival when transfused into a normal circulation may be explained by supposing either that the sensitization is reversible in the medium of a normal circulation, or that in acquired haemolytic anaemia there is an additional factor causing the rapid elimination of the sensitized-cells.

We have attempted to determine which of these suppositions is correct, and to ascertain whether transfused normal cells become sensitized before elimination from the circulation of patients with acquired haemolytic anaemia. We have examined the erythrocytes from five patients, all of whom gave a positive direct Coombs test, and present in this paper the detailed results of our investigation of three of these patients. The fafe of normal erythrocytes transfused to these patien's and of the erythrocytes from one of them (Case 8 transfused to two normal recipients was studied b means of differential agglutination counts emplo ing Mollison's (1947) modification of Ashbygas (1919) method. This technique was further modf fied to enable sensitized and unsensitized cells to be distinguished from each other: that is, "diffe 3 ential direct Coombs counts" were undertaken.

\section{Experimental Methods}

The transfused erythrocytes in the recipient's circwlation were estimated by differential agglutination tests as a percentage of the total erythrocyte count. An approximately 2 per cent cell suspension in isotonge ( 0.85 per cent) saline was made from the recipients blood. This suspension was mixed in known volumes in glass tubes ( $2 \frac{1}{2}$ in. by $\frac{1}{2}$ in.) with isotonic saline and with the chosen anti-serum to give in each case a fin cell suspension of approximately 0.1 per cent. The total number of cells per c.mm. in the saline mixtuft was counted. The anti-serum cell mixture was treated as follows (Mollison, 1947):

(1) The mixture was allowed to stand for at leas: 1 hour at room temperature, or at $37^{\circ} \mathrm{C}$. if anti-Rd serum was being used; (2) it was centrifuged at 1,000 r.p.m. for 1 minute, and the deposit resuspended by shaking with moderate vigour; (3) centrifuging and resuspension were twice repeated; (4) the tube wass stood vertically for a few seconds to allow the large clumps to sediment, and a drop of fluid was trans ferred from the top of the column to each of twe counting-chambers, using a Pasteur pipette; (5) th unagglutinated cells were counted, and from the average count per c.mm. the percentage of unaggluttr. nated cells in original suspension was calculated ; the 
number per c.mm. in the recipient's blood was then derived from the total erythrocyte count.

Differential direct Coombs counts were performed 'in a similar manner. Suspensions of thrice-washed cells in isotonic saline were treated as described above after having been mixed with volumes of fully absorbed high titre anti-human-serum rabbit serum prepared at this centre by the method of Coombs and Mourant (1947). This serum was used at a final dilution of 1/100 (full titre against cells sensitized with anti-Rh incomplete antibody being 2,000 ), and the mixture was allowed to stand for half an hour.

The accuracy of the differential Coombs count was tested with known mixtures of normal cells and cells sensitized in vitro with an incomplete anti-D serum, and with mixtures of normal cells and sensitized cells from one of the patients described below. The results always agreed with the calculated percentage of sensitized cells within the limits of \pm 5 per cent. With pure suspensions of sensitized cells the unagglutinated cells numbered about 1 per cent of the total.

The number of sensitized cells per c.mm. of the recipient's blood was calculated as above. The recipient's own erythrocyte count was derived from the total and transfused erythrocyte counts. Reticulocytes were estimated as a percentage from a stained blood film and the actual count per c.mm. calculated.

\section{Case Reports}

A. The Fáte gr Normal Erythrocytes Transfused* to Patients With AcQuired Haemolytic ANAEMIa

Case 1.-A man aged 70 years had had symptoms for two years. He had moderate pallor and icterus and an enlarged spleen. The blood film showed moderate anisocytosis and polychromasia, 50 per cent reticulocytes, and very occasional late normoblasts. There was raised serum bilirubin and urinary urobilin, and markedly increased erythrocyte fragility with spherocytosis. No cold auto-agggluti-

-Stored blood was used for the transfusions in this group of patients. The percentage of non-viable cells it contained in each caso was calculated from the results of Ross and others (1947): it was approximately 5 per cent, 3 per cent, and 2 per cent respectively in Cases 1, 2, and 3 . Most of these non-viable cells would have been eliminated in two hours after entering the circulation have been eliminated in two hours after entering

of the recipient, and the remainder within 24 hours.
The blood for transfusion was cross-matched by incubating a cell suspension in saline with the recipient's serum at $37^{\circ} \mathrm{C}$. for at least 1 hour. No agglutination was observed to have occurred and an indirect Coombs test was then performed on the red cells, which were negative even when the incubation was prolonged on one occasion (Case 1) for 6 hours, and on arother (Case 2) for 24 hours. nins, immune agglutinins, or incomplete antibodies were demonstrable in serum. The direct Coombs test on erythrocytes was strongly positive. The blood group was B, D-positive. Normal group B, D-negative blood was transfused, and differential counts were carried out with a specific anti-D agglutinating serum (titre 512 and used at a final dilution of $\frac{1}{4}$ ) from a group AB, D-negative woman immunized by pregnancies.

Two days after a transfusion of 2 pints of packed cells (Fig. 1) the circulating blood contained 900,000 sensitized cells per c.mm. of blood and 250,000 of the patient's own cells per c.mm. Four days later the total of sensitized cells had increased by 780,000 per c.mm., although the patient's own cells had increased by only 350,000 per c.mm. From these findings it was concluded that some of the transfused cells had become sensitized during the latter four days.

From the sixth to the twelfth day the sensitized cell count fell steadily and rapidly, parallel to the fall in the transfused cell count; the patient's own cell count 
slowly rose. These changes support the conclusion that a proportion of the sensitized cells were transfused cells.

Case 2.-A woman aged 42 years had had symptoms for three months. She had marked pallor with slight icterus and an enlarged spleen. The blood film showed moderate anisocytosis and polychromasia, 20 per cent reticulocytes, and very occasional late normoblasts. The serum bilirubin and urinary urobilin were raised, and the erythrocyte fragility was slightly increased. The patient's serum contained a cold auto-agglutinin (in saline dilutions titre 4 at $4^{\circ} \mathrm{C}, 1$ at $15^{\circ} \mathrm{C}$, no activity at $37^{\circ} \mathrm{C}$.), but no immune agglutinins or incomplete antibodies were demonstrable. The direct Coombs test was strongly positive; differential tests showed that 96 to 99 per cent of the erythrocytes were sensitized. The blood group was O, D-negative type MN. Normal group O, D-negative, type $\mathbf{N}$ blood was transfused, and a specific naturally-occurring anti-M serum (titre 32 ) from a blood donor was used at a final dilution of $\frac{1}{2}$ in the differential agglutination counts. (This anti-M serum did not cause any non-specific agglutination such as may be found with artificially prepared anti-M or anti- $\mathrm{N}$ rabbit sera.)
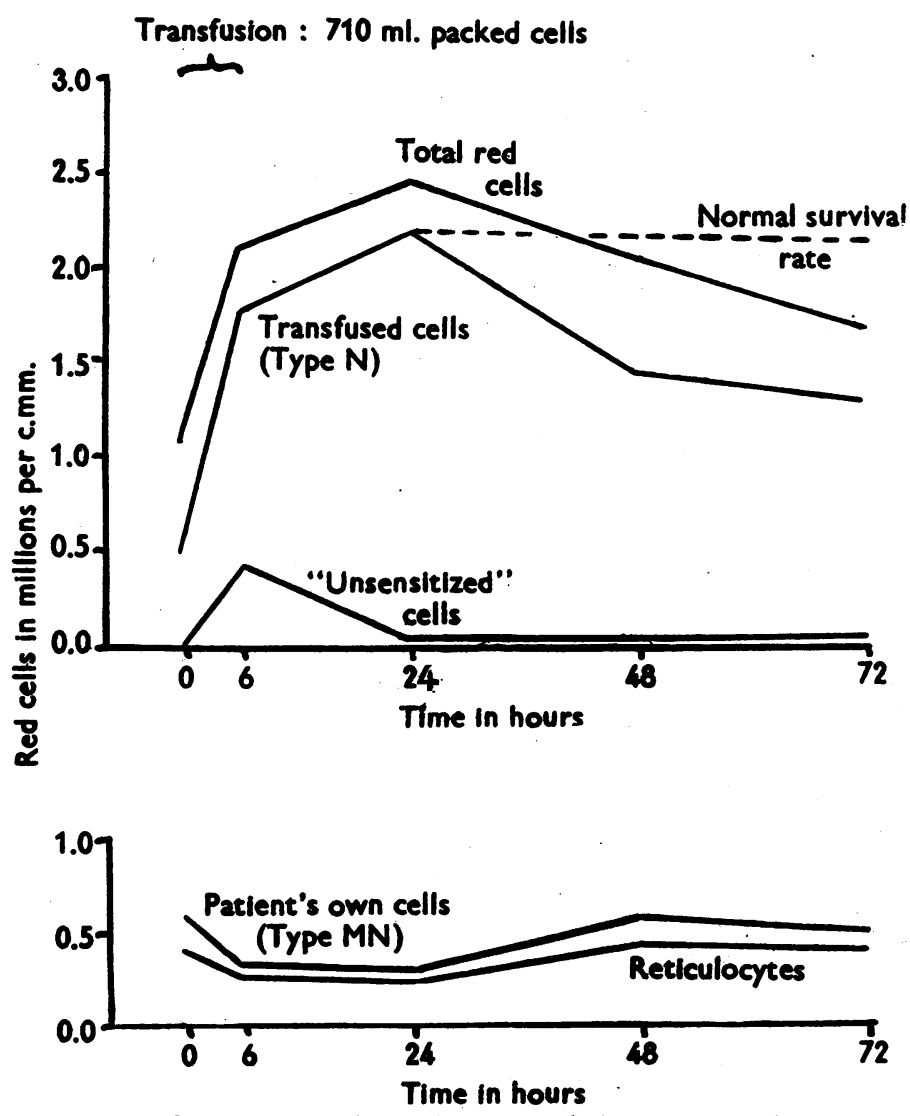

Fig. 2.-Progress of Case 2. Lower half shows mottling.
This patient destroyed transfused cells very rapidly on one occasion the transfused cell count fell fror? $1,550,000$ per c.mm. to 500,000 per c.mm. of blood in. 7 days, an elimination of 63 per cent.

In Fig. 2 the M-negative cells present at the start were survivors of previous transfusions. Immediatel after the tranfusion of $1 \frac{1}{2}$ pints of packed cells ther were 1,300,000 M-negative cells per c.mm. of bloop However, the unsensitized cell count had risen by onlo 380,000 per c.mm., which suggested that the majorito of transfused cells had already become sensitized, Eighteen hours after the end of the transfusion all the cells were sensitized, the increase in the transfused cell count being probably due to the adjustment o d circulating blood volume after a blood transfusion (Mollison, 1947). From this time onwards the trans fused cell count decreased rapidly -59 per cent of the cells being eliminated in forty-eight hours.

Case 3.-A girl aged 10 years had pallor and slight enlargement of liver and spleen. Many reticulocytes could be seen in the blood film, and the bone marrow was normoblastic. The serum bilirubin and urinary urobilin were raised, and the erythrocyte fragility wo at the upper limit of normal. The direct Coombs test was strongly positive, 96 per cent $\phi$ the cells being sensitized. Her serum contained a cold auto-agglutinin at $₫$ similar titre to that of Case 2 ; immune agglutinins or incomplete antibodies were demonstrable. Tir blood group was A, D-positive. Bloog of group $\mathrm{O}, \mathrm{D}$-positive, was transfuse $\$$ and a stock grouping anti-A serum (titre 512) was used at a final dilutio of $\frac{1}{4}$ for the differential agglutination counts. Fig. 3 shows the resu质 obtained after the anaemia had already been relieved to a certain extent group A blood transfusions.

Ten hours after the transfusion of 2 pints of blood the group $O$ id count had risen by $1,490,000$ per c.mm. of blood, and the unsensitized cell count by 430,000 per c.mm. Pre sumably, approximately $1,060,000 \mathrm{p}$ c.mm. of the transfused group $O$ ce盾 had become sensitized. Two dax̄ after the transfusion the unsensitized cell count had fallen to its base-line of about 100,000 per c.mm. of bloo $\$$ indicating that all the transfused cells had become sensitized. The transfuse cells were rapidly eliminated, 45 per cent within ten days.

B. The FATE OF ERYTHROCYTES PROIJ

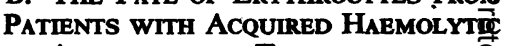
ANAEMIa WHEN TRANSFUSED to Normal Recipients

Case 4.-The second part of the investigation was carried out with 
blood taken from Case 2 into acidcitrate dextrose solution. The cells settled rapidly owing to the presence of the cold auto-agglutinin and, after half an hour, $80 \mathrm{ml}$. of the settled cells were transfused into a two-weeks-old baby who had inoperable spina bifida with paraplegia (Case 4). Ninety-six per cent of the cells were sensitized. The recipient's cells were Group A, and before the transfusion were completely unsensitized.

Differential agglutination counts twenty-four hours after the transfusion (Fig. 4) showed that 1,350,000 Group $O$ cells per c.mm. of blood had been introduced by the transfusion and that there were $1,900,000$ sensitized cells per c.mm. As the sensitized cell count rose even higher during the succeeding days, it became apparent that the recipient's cells were becoming sensitized as the result of the transfusion.

About 50 per cent of the transfused cells were eliminated during the next three days, but subsequently the rate of disappearance became less and less rapid until from about the sixteenth day onwards the cells were being eliminated at the rate of normal healthy adult cells. The transfused cell counts have been corrected for changes in the recipient's body-weight.

In order to determine whether the surviving transfused cells were still sensitized, as complete a separation as possible of the transfused cells was made from the recipient's blood in the following way: A heavy cell suspension of the recipient's blood in saline was made, and anti-A serum added as for a differential agglutination count. After the third centrifuging the supernatant fluid was removed and the cells resuspended in saline. After the large clumps had been allowed to settle for about a quarter of an hour the supernatant suspension was removed and subjected to the differential agglutination procedure again. After the third centrifuging the cells were resuspended and allowed to settle for half an hour. The supernatant suspension was removed, and the cells in it washed and tested with anti-human-serum rabbit serum.

The final suspension so obtained on the thirty-eighth day after transfusion contained 100 per cent Group $O$ cells (transfused cells), of which 97 per cent were sensitized. On the forty-fifth day a similar suspension contained 88 per cent Group $O$ cells, and again 97 per cent were sensitized. These results indicate that the transfused cells had remained sensitized whilst in the recipient's circulation.

The sensitized cell count of the recipient's blood after the transfusion rose steadily for nine days, until
Transfusion : $1.080 \mathrm{ml}$. blood
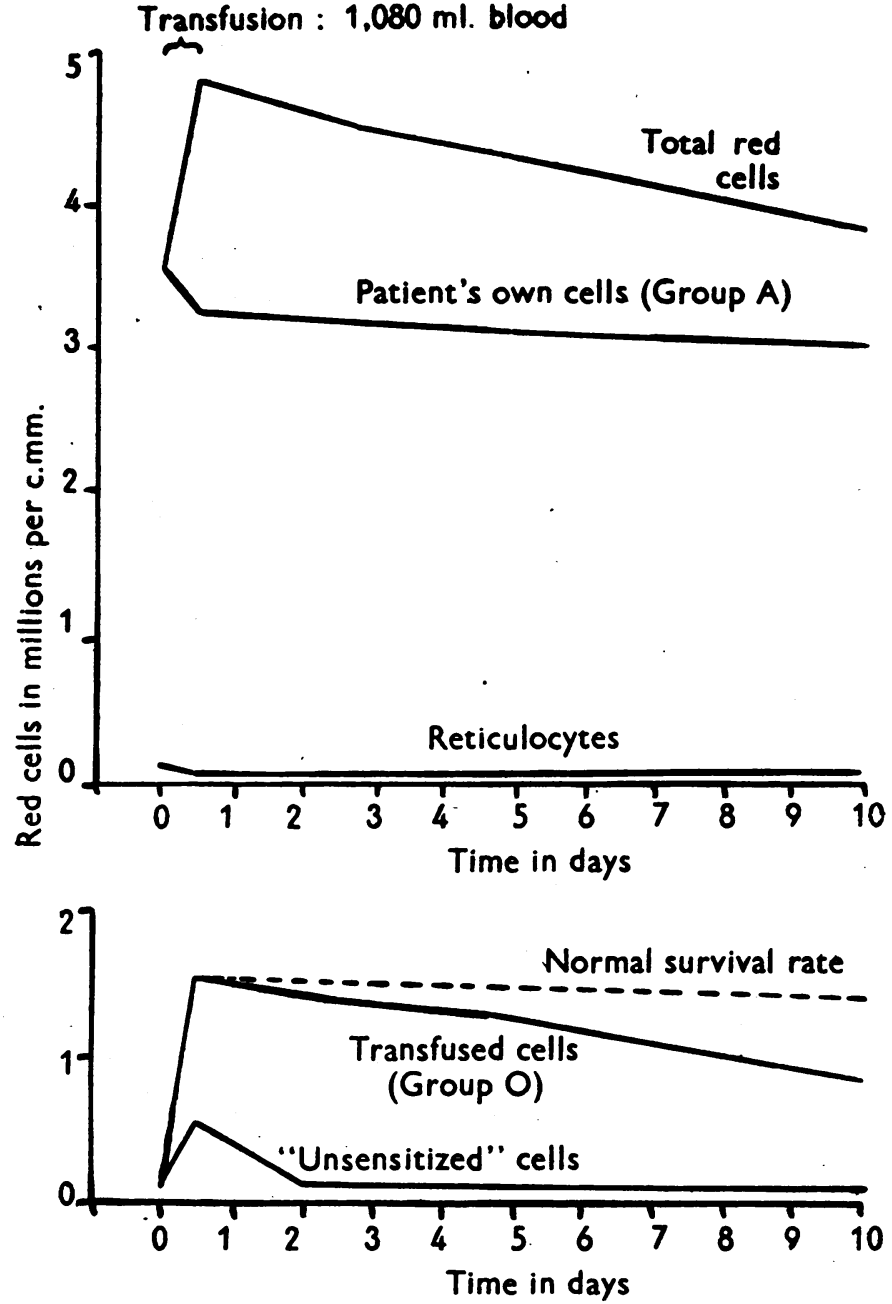

Fig. 3.-Progress of Case 3.

65 per cent of the recipient's own cells were sensitized, assuming the transfused cells to be sensitized as the above results indicate. One month later the recipient's general condition deteriorated spontaneously because of the. congenital neurological abnormality, and the total erythrocyte count fell markedly. Eightyfive per cent of the recipient's own cells were then sensitized.

Case 5.- Seven weeks after Case 2 had undergone splenectomy and had improved thereby, blood was again taken from her into acid-citrate dextrose solution. After the cells had settled for one hour at $4^{\circ} \mathrm{C}$., $100 \mathrm{ml}$. of the supernatant plasma were transfused into a recipient of blood Group B and similar to Case 4. No sensitized cells were detected in the recipient's blood during the following six days. Later, $100 \mathrm{ml}$. of whole blood from Case 2 were transfused, 98 per cent of the cells in this blood being sensitized. 
Transfusion : $80 \mathrm{ml}$. packed cells from Case 21
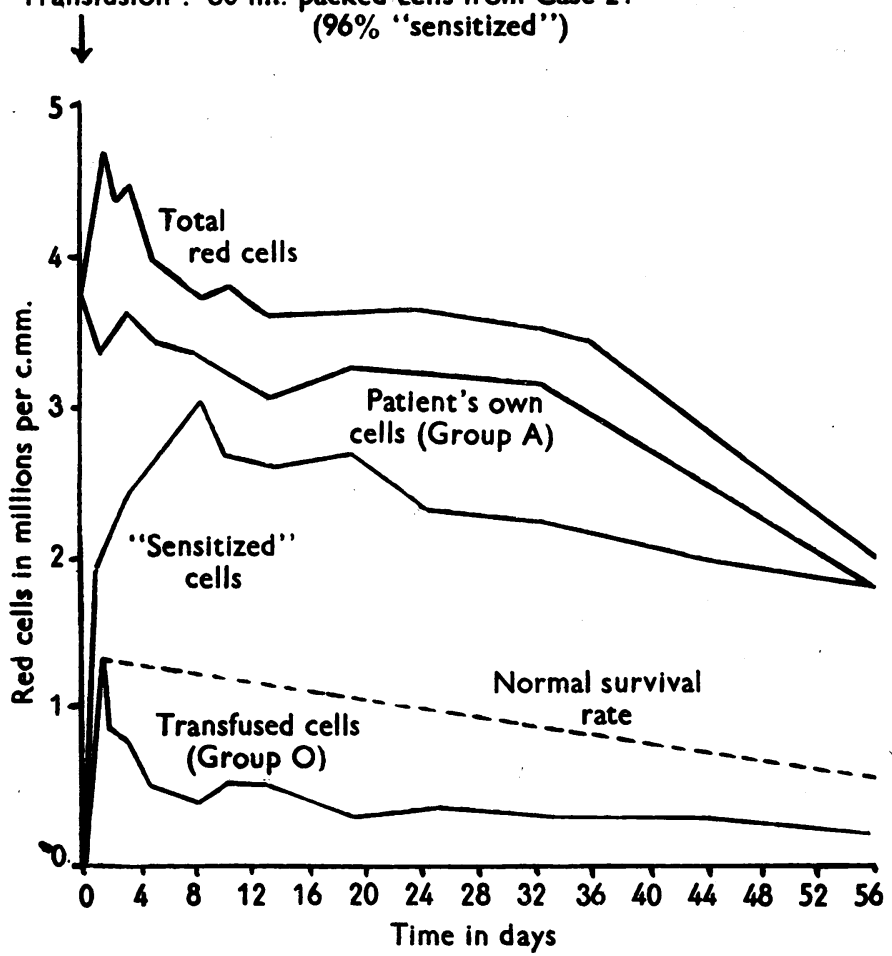

Fig. 4.-Differential agglutination counts after transfusion of Case 4 with blood taken from Case 2 into acid-citrate dextrose solution.

After twenty-four hours there were $1,150,000$ Group $O$ cells per c.mm. of blood and 4,860,000 sensitized cells per c.mm. out of a total erythrocyte count of 5,230,000 per c.mm. As shown in Fig. 5, the transfused Group $O$ cells have been assumed to be still sensitized and for purposes of charts their total has been subtracted from the total sensitized cell count so as to give the recipient's sensitized cell count. It thus appears that about 95 per cent of the recipient's own cells become sensitized, and that this percentage remained constant during the next twenty-seven days, after which it started to decrease, falling to 70 per cent by the forty-second day after the transfusion.

To check the assumption that the transfused cells were still sensitized, a suspension of transfused cells was prepared on the twenty-eighth day after the transfusion by the method described above (Case 4). Differential counts showed it to contain 100 per cent Group $O$ transfused cells, 90 per cent of which were sensitized.

The transfused cells were eliminated more slowly than in Case $4 ; 30$ per cent disappeared during the first ten days, but thereafter they were eliminated at the rate of normal adult cells. The counts have been corrected for changes in the recipient's body-weight.

\section{Discussion}

The erythrocytes of patients with acquired haemolytic anaemia give a positive direct Coombs test (Boor-을 man and others, 1946), suggesting that a change has taken place on the cell surface, perhaps due to the $\mathbb{\complement}$ adsorption of an immune auto-零 antibody.

Our finding that normal cells. become sensitized and give a posi- $\vec{\omega}$ tive direct Coombs test when trans-? fused into a patient with acquired haemolytic anaemia, before beingiv eliminated from the recipient's cir-? culation, provides further evidence $\overrightarrow{-}$ that an antibody or sensitizing agent initiates the haemolytic process. This antibody is evidently non-specific ; and following sensitization the transfused cells are eliminated more rapidly than is normal.

Our investigations have confirmed. the findings of Loutit and Mollison (1946) that cells from cases of acquired haemolytic anaemia can sur-o vive normally when transfused intő a normal recipient. This fact, Loutito and Mollison suggested, indicates $\vec{\overrightarrow{ }}$ that sensitization per se is not 3 enough to ensure the premature haemolysis of cells in acquiredo haemolytic anaemia ; and they have postulated the presence in such cases of either a co-haemolysino or a " pathologically potentiated spleen," either of which might complete the destruction of the cells. The survival of sensitized cells in a normal circulation could then be explained by the absence of the additional haemolytic mechanism, or alternativelys the sensitized cells might lose their sensitization in a normal circulation.

We have shown that such cells remain sensitizedo during their life in the normal circulation, and thus it seems that their increased resistance undern such conditions is not due to the sensitization having been reversed.

The theory that a pathologically potentiated spleen may cause the rapid destruction of thes. sensitized cells is supported by the fact that an enlarged spleen is a characteristic finding in acquired haemólytic anaemia, and that splenecs] tomy is followed in some cases by clinical improvement. Of the three patients studied by us, however, Cases 1 and 2 were treated only by 
repeated blood transfusions. They have remained well without further treatment for eighteen months and four months respectively. . Case 3, after similar transfusion therapy, had a clinical remission, but a month later she relapsed and splenectomy was performed. She has since remained well for three months. Therefore it seems that any abnormal splenic activity in this condition must be very variable.

Our finding that a proportion of the patient's cells are rapidly eliminated in a normal subject suggests that it may not be necessary to postulate the presence of an accessory haemolytic factor. Although the fate of the red cells may not ne finally determined by the sensitization itself, it may depend on the degree of sensitization. Blood from two of the patients with acquired haemolytic anaemia studied by Loutit and Mollison (1946) was eliminated at a faster rate than normal for the first week after transfusion to normal . subjects, but survived normally thereafter. In both our cases this initial rapid elimination rate was seen, but once again survival was subsequently normal. Brown and others (1944) showed that, when the normal elimination of normal transfused cells is plotted as a graph, the result is linear, while elimination by a haemolytic mechanism results in an exponential curve. Figs. 4 and 5 show that for approximately the first ten to fifteen days a haemolytic mechanism was at work, but that after this time it ceased to act. The elimination subsequently continued in the normal linear way, in spite of the transfused cells still remaining sensitized. This could be explained by supposing that haemolysis of sensitized erythrocytes in the normal body occurs only amongst those cells which are heavily sensitized. Those which carry more than a certain threshold dose are rapidly eliminated, others less heavily sensitized surviving normally. It is reasonable to suppose that some cells from a patient with acquired haemolytic anaemia carry a heavier dose of antibody than do others. The fact that it has always been so difficult to demonstrate free antibody in the sera of such cases (Neber and Dameshek, 1947) indicates that it is taken up by the circulating cells very soon after it has been formed, and so these cells which have been circulating longest may carry more antibody than the newcomers.- If this is so it would seem possible that the abnormal haemolysis in acquired haemolytic anaemia depends upon the continued sensitization of the patient's erythrocytes by a non-specific auto-antibody until sensitization reaches a certain threshold. When this threshold is reached the cells are eliminated by the normal processes of the body.

Mo!lison (1948) transfused infants with normal cord blood and found that the transfused cells were relatively rapidly eliminated during the first ten days and that this was followed by a normal rate of elimination. He suggested that the macrocytes in newborn infants' blood might survive less well than the normocytes. Our last two cases (4 and 5) were infants who received blood containing many macrocytes. The presence of these macrocytes may in part be responsible for the initial rapid elimination of transfused cells in these two cases.

The spread of sensitization among the normal cells of our last two cases, as shown in Figs. 4 and 5 , is probably due to a redistribution of the 
antibody actually attached to the transfused red cells, since no demonstrable sensitization occurred after the transfusion to Case 5 of fresh plasma from Case 2. This redistribution could be explained by supposing either that the antibody is set free again when a transfused cell is haemolysed and that it re-attaches itself to a normal cell, or that it is a simple sharing of the antibody between the transfused cells and the recipient's normal cells. Evidence for the former supposition is found in the fact that the peak in the spread of sensitization among the recipient's cells in Fig. 4 was reached at the same time as the exponential mechanism acting on the transfused cells gave way to a normal linear elimination.

Although the majority of the recipient's cells (Cases 4 and 5) became sensitized as a result of the transfusion of blood from a case of acquired haemolytic anaemia, no ill-effects, reticulocytosis, or other signs of acquired haemolytic anaemia were observed.

The Coombs test, at present, is purely qualitative and does not indicate how strongly a cell may be sensitized. It might be possible to modify the counting technique, perhaps by employing lower concentrations of anti-globulin serum, so as to show that some cells are more easily agglutinable with dilute anti-serum than others. In this way further evidence might be obtained as to the relationship between the degree of sensitization and the abnormal breakdown of the erythrocytes in acquired haemolytic anaemia.

\section{Summary}

1. The survival of normal erythrocytes transfused to three patients with acquired haemolytic anaemia was studied by means of differential agglutination counts. Differential direct Coombs $\underline{\overrightarrow{0}}$ counts were also performed and the results indicate that the transfused cells become "sensitized " before being eliminated at a rate greater than normal.

2. Blood from one of these patients transfused $\frac{\bar{C}}{\vec{D}}$ into two normal recipients was eliminated at an $\varrho$ increased rate for the first ten to fifteen days and $\%$ thereafter at a normal rate. The transfused sensi- $\vec{\circ}$ tized cells remained sensitized during their life in the normal circulation.

3. The recipient's own cells became sensitized as a result of the transfusion of sensitized cells.? Possible explanations are considered.

4. In acquired haemolytic anaemia the erythro- $-\overrightarrow{-}$ cytes are sensitized, probably by a non-specific $\vec{\overrightarrow{ }}$ auto-antibody. The possible processes that may음 play a part in the rapid elimination of these sensi- $\rightarrow$ tized cells are discussed.

We wish to thank Dr. Phillips, superintendent of $\vec{\theta}$ Southmead Hospital, for permission to publish the case-notes, and Dr. Corner for access to Cases 4 and 5. We are indebted to Dr. Tovey, Regional Blood Trans- $\square$ fusion Officer, and Professor Neale for their helpfulo criticism and advice.

\section{REFERENCES}

Ashby, W. (1919) J exp. Med., 29, 267.

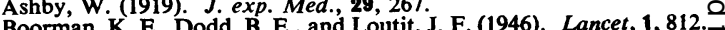
Brown, G. M., Hayward, O. C., Powell, E. O., and Witts, L. J. (1944). $\overrightarrow{\bar{O}}$ J. Path. Bact., 56, 81.

Coombs, R. R. A., Mourant, A. E., and Race, R. R. (1945a). Lanect, 2,15 . 2, 15.
Coombs, R. R. A., Mourant, A. E., and Race, R. R. (1945b). Brit. J
exp. Path., 26, 255.

Coombs, R. R. A., and Mourant, A. E. (1947). J. Path. Bact. 59, 105 .

Dacie, J. V., and Mollison, P. L. (1943). Lancet, 1, 550.

Dacie, J. V., and Mollison, P. L. (1946). Lancet, Path. Bact., 58, 711.

Mollison, P. L. (1947). Clin. Sci., 6, 137.

Mollison, P. L. (1948). Lanicet, 1, 513.

Neber, J., and Dameshek, W. (1947). Blood, 2, 371.

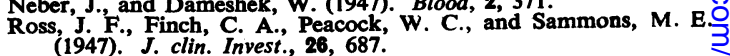

